\title{
INTERNET SEBAGAI MEDIA INTERAKTIF DISALAHGUNAKAN OLEH ELIT POLITIK
}

\author{
Maulana Andinata Dalimunte, Fadlan Ananda Lubis \\ Universitas Gadjah Mada, Yogyakarta, Indonesia
}

\begin{abstract}
Abstrak
Keterbukaan Informasi dan kebebasan berpendapat serta berpikir merupakan hakhak dasar manusia sebagai warga negara. Keterbukaan Informasi dan kebebasan berpendapat banyak disalahgunakan oleh elit politik. Akan tetapi, tidak sedikit elit politik yang melakukan kampanye hitam dan kampanye negatif di internet. Praktek-praktek penyalahgunaan informasi ini justru merugikan masyarakat. Penyelahgunaan informasi ini biasanya dilakukan dengan memuat konten yang berbau SARA (Suku, Agama, Ras dan Antargolongan) disebarkan melalui media sosial atau websites bertujuan untuk mencemaran nama baik lawan politik agar mendapat citra negatif. Seperti, kasus Saracen yang memanfaatkan media sosial dan internet untuk menyebarkan serta mengelola isu SARA yang dipromotori oleh sejumlah elit politik. Bukan tidak mungkin kegiatan yang dilakukan oleh Saracen tersebut menimbulkan konflik di tengah masyarakat sehingga dikhawatirkan menyebabkan terpecah belahnya persatuan dan kesatuan bangsa. Kampanye hitam dan kampanye negatif diatas jika dibiarkan menjadi kondisi yang kontradiktif antara kehadiran internet yang diharapkan mengembangkan komunikasi politik justru disalahgunakan oleh elit politik. Oleh karena itu masyarakat dalam hal memenuhi kebutuhan akan informasi harus mengenal konten yang tersebar di internet dan memahami dinamika komunikasi politik di era virtualitas seperti sekarang ini. Namun, keterlibatan pemerintah sebenarrnya sudah ada untuk mengatasi masalah penyalahgunaan informasi dan transaksi elektronik dengan mengaturnya di UU ITE .
\end{abstract}

\section{Kata Kunci: Media Baru, Internet, Komunikasi Politik, Elit Politik}




\section{Pendahuluan}

Indonesia termasuk negara yang menganut sistem demokrasi pancasila. Demokrasi pancasila sebagai ideologi negara dan rakyat sebagai pemegang kekuasaan sangat berpengaruh dalam sistem dan tatanan negara. Kelima asas pancasila sebagai akar pedoman pembuatan regulasi dijunjung tinggi oleh setiap warga negara. Indonesia tidak bisa sewenangnya memberikan kebebasan suatu masyarakat tanpa ada batasan. Karena, hal tersebut akan menimbulkan banyak konflik yang bertentangan dengan asas-asas Pancasila. Seperti memperbolehkan praktek-praktek penyalahgunaan informasi dan konsumsi publik. Hal tersebut dapat menyebabkan terpecah belahnya persatuan dan kesatuan bangsa Indonesia. Terpecah belahnya persatuan dan kesatuan bangsa Indonesia belakangan ini dipengaruhi oleh dinamika pemilihan umum yang diperankan oleh orangorang yang berkecimpung dibidang politik. Dalam prakteknya, elit politik menggunakan media untuk berkampanye dan sering sekali disalahgunakan. Maka dari itu pengaruh media terhadap warga negara Indonesia sangat besar peranannya terhadap keberlangsungan demokrasi di Indonesia.

Internet sebagai teknologi yang sering digunakan oleh masyarakat dalam mengakses informasi dapat memangkas sekaligus menggabungkan media televisi, radio, film dan koran. Dalam pelayanannya internet disambut positif warga negara Indonesia bahkan dunia. M. Poster dalam Nimmo (2005) menyatakan bahwa Internet melampaui batasan-batasan model media cetak yang memungkinkan model many-to-many, resepsi, alteration and re-distribution objek kultural secara simultan, mendislokasi tindak komunikatif dari batas-batas bangsa serta memberikan kontak global pada saat itu juga. Penyebaran berita dengan kecepatan tinggi, kemudahan akses dan lebih adaptif terhadap pengguna merupakan kelebihan dari media baru dalam memanfaatkan internet. ${ }^{1}$ Internet sebagai media interktif banyak dimanfaatkan oleh elit politik dan memegang peranan penting dalam proses komunikasi politik.

Elit politik sendiri menurut Vilfredo Pareto dalam Varma (2010: 200) ialah kelompok orang yang mempunyai indeks kemampuan yang tinggi dalam aktivitas mereka apapun bentuknya, akan tetapi elit politik kemudian mengkonsentrasikan diri pada apa yang disebut sebagai "elit penguasa" yang dipertentangkan dengan massa yang tidak berkuasa. $^{2}$ Artinya, ada dua kelas manusia, kelas yang berkuasa dan kelas yang dikuasai kemudian elit merupakan orang-orang yang mampu menduduki jabatan yang tinggi di masyarakat. Dalam prakteknya elit politik melakukan sosialisasi dan kampanye politik dengan menggunakan media internet.

\footnotetext{
${ }^{1}$ Nimmo, Dan. (2005). Komunikasi Politik. Komunikator, Pesan, dan Media Bandung: Remaja Rosda Karya.

${ }^{2}$ Varma, S.P. (2010). Teori Politik Modern. Penyunting Tohir Efendi. Jakarta: PT. Raja Grafindo Persada. Hal: 200
} 
Sifat internet yang interaktif memungkinkan proses komunikasi politik bisa dilakukan lebih intens antara elit politik dan masyarakat. Elit politik sadar betul untuk memperoleh simpati dari masyarakat mereka harus memiliki citra yang baik. Akan tetapi untuk memperoleh citra baik dari masyarakat elit politik cenderung "menghalalkan segala cara". Seperti, kasus Saracen yang merupakan sindikat penyebar ujaran kebencian atau isu SARA (Suku, Agama, Ras, Antargolongan) dan hoax yang diduga kuat jasa Saracen dipakai oleh sejumlah elit politik. Sesuai dengan yang dikatakan penyidikan Kanit V Subdit III Direktorat Tindak Pidana Siber Bareskrim Polri AKBP Purnomo pada laporan berita Tribunnews.com: "Kalau ditanya siapa yang pesan atau ada kaitan parpol, sebenarnya dalam bukti digital, ada gambar (foto) dari para tersangka yang bersama tokoh-tokoh parpol. Ketika ditanya, mereka ngakunya hanya fans,". 3

Fenomena adanya dan berkembangnya sindikat Saracen diatas menarik untuk dilihat. Bukan tidak mungkin jika dibiarkan sindikat-sindikat lain akan bermunculan. Kasus Saracen menggunakan Internet khususnya media sosial sangat kontradiktif dengan harapan awal penggunaan internet sebagai media yang dapat memudahkan komunikasi politik antara elit politik dan masyarakat. Oleh karena itu penting bagi masyarakat untuk mengkaji dan melihat dinamika pemanfaatan internet dalam kehidupan politik yang sedang berkembang.

Internet melahirkan suatu masyarakat jaringan yang lebih banyak melakukan aktivitasnya di ruang berbasis digital. Merebaknya isu-isu politik yang datang silih berganti, seperti isu kampanye hitam yang dilakukan oleh seorang elit politik atau kasus Saracen yang mengandung isu SARA di atas pada satu sisi menjadi banyak perbincangan warga netizen. Kualitas penerimaan serta literasi media merupakan kemampuan yang harus dimiliki masyarakat agar dapat bersikap lebih bijak mengingat negara Indonesia adalah negara yang menganut sistem demokrasi.

Bahkan bagi setiap orang internet dianggap lebih efektif dari pada media meinstream seperti surat kabar dan televisi dalam hal penyampaian informasi. Dapat dilihat dengan hadirnya media baru seperti internet sangat dibutuhkan dalam segala aspek, termasuk aspek politik sebagai ajang popularitas dan elaktabilitas tokoh politik maupun partai politik. Dalam tulisan ini penulis memapaparkan "bagaimana perkembangan teknologi media baru seperti internet disalahgunakan oleh elit politik dalam memperoleh suara publik".

\section{Pembahasan}

Media dapat dipahami sebagai sebuah titik pertemuan dari banyak kekuatan yang berkonflik dalam masyarakat modern. Oleh karena itu, tingkat kerumitan isu dalam media tinggi. Hubungan antara pemerintah, media dan politik merupakan masalah globalisasi

\footnotetext{
3 http://www.tribunnews.com/nasional/2017/09/21/polisi-pegang-bukti-foto-keterlibatan-tokoh-parpoldalam-sindikat-saracen.
} 
dan lokalitas, keduanya menjadi hal yang kontroversial dalam kajian media umumnya. Ada karakter yang berlawanan dari dinamika media pada era pasca Soeharto yang memunculkan perubahan politik secara drastis yang telah membawa Soeharto turun dan memberi jalan yang lebih demokratis dan liberasi media, dimana mengarah pada munculnya ruang publik dan civil society di Indonesia. Lengsernya masa kepemimpinan soeharto dan seiring waktu kepemimpinan presiden Jokowi sekarang tidak lepas dari permasalahan penggunaan dan pemanfaatan media di Indonesia. Kepemimpinan yang baru ini juga memberikan permasalahan yang baru pula.

Dalam membahas internet sebagai media interaktif yang disalahgunakan oleh elit politik. Kita tidak bisa lepas dari peran internet sebagai mediasi antara masyarakat dan elit politik serta tujuan tertentu yang ingin diraih oleh keduanya. Pada bagian ini penulis ingin membahas bagaimana: (1) media sebagai mediator masyarakat informasi, (2) internet dan komunikasi politik dan (3) citra serta dinamika elit politik dalam era virtualitas.

\section{Landasan Teori}

Media online atau internet merupakan media baru, dapat dikatakan sebagai penemuan teknologi tercanggih yang paling fenomenal yang ditemukan manusia. penemuan internet sebagai alat komunikasi memiliki karakteristik serta cirinya tersendiri yang membedakan dan menjadikan media ini sebagai media yang paling fenomenal diantara media media lainnya. Manusia sebagai makhluk yang memiliki akal akan terus berkembang terkait dengan kehidupan dan lingkungannya. Oleh karena itu, berbagai penelitian dan pengembangan berbagai alat teknologi komunikasi terus berkembang.

Namun sampai saat ini internet merupakan bentuk capaian tertinggi dalam pengembangan teknologi komunikasi. Dalam memanfaatankan internet kita tidak bisa lepas dari aspek serta motif seseorang dalam penggunaannya. Seseorang berperilaku karena terdorong oleh kebutuhan. Asumsi ini pada dasarnya berawal dari setiap manusia membutuhkan informasi untuk penunjang kehidupannya, baik dalam tuntutan profesi dan pemenuhan kebutuhan. Oleh sebab itu, tidak mengherankan jika dinamika informasi, diwarnai oleh aplikasi teknologi komunikasi dari tingkat sederhana yang tersebar ke seluruh lapisan masyarakat maupun yang memiliki tingkat pemrosesan, penyimpanan dan aplikasi lain yang menunjukkan kecanggihan teknologi komunikasi informasi. Keterbukaan Informasi dari pemerintah dan kebebasan berpendapat serta berpikir merupakan hak-hak dasar manusia sebagai warga negara.

Berdasarkan data statistik yang dikeluarkan oleh internet Word Stats, jumlah populasi penduduk dunia tahun 2007 sebanyak 6.606.971.659 jiwa. Sejak tahun 2000, pengguna internet di bulan desember 2007 telah meningkat sebanyak 265,5\% atau menjadi 1.319.872.109 pengguna internet. Dari jumlah tersebut, internet diseluruh dunia jumlah penggunanya terbesar di 20 negara. Seperti, Amerika, Jepang, Jerman, Inggris, 
Korea Selatan, Prancis Italia, Australia, Taiwan, Kanada yang populasinya relatif besar. ${ }^{4}$ Internet bukan hanya dapat mempengaruhi pola pikir akan tetapi dapat mempengaruhi seluruh aspek kehidupan manusia baik itu mencakup aspek sosial, budaya, ekonomi, perthanan keamanan, hubungan antar pribadi, lintas bangsa, agama dan negara.

Menurut Bambang Cipto (2003:105) dewasa ini internet telah menjadi media yang cukup besar pengaruhnya terhadap perubahan politik dalam masyarakat. Hampir semua hal yang berkait dengan politik dan pemerintahan bisa diakses lewat websites mereka masing-masing. ${ }^{5}$ Di Indonesia sendiri penyelenggara jasa internet (PJI) (Internet Service Provider ISP) menggunakan tiga saluran pengirim dan penerima sinyal baik kabel, radio maupun VSAT dengan satelitnya. Tujuannya adalah untuk kepentingan pertukaran dan penyebar luasan informasi. Namun, kehadiran internet sangatlah berpotensi sebagai ancaman bagi pemakainya. Sehingga diperlukan kebijakan yang memungkinkan literasi digital dapat berjalan bersinergi dengan literasi media masyarakat mengingat ada seseorang atau sekelompok orang yang memanfaatankan internet untuk kepentingan tertentu sehingga "menghalalkan segala cara". Seperti, elit politik yang menggunakan kampanye negatif maupun kampanye hitam.

Kampanye negatif sudah biasa terjadi dalam ranah perpolitikan di Indonesia, adapun kampanye negatif berkenaan dengan tindakan tindakan kandidat yang ingin memenangkan pemilihan umum dengan cara menyerang lawan dari pada menekankan sisi positif lawan dan kebijakannya. Lilleker (2006:127) mengatakan bahwa dalam faktanya sebagian besar kandidat membuat referensi negatif diantaranya bisa berubah menceritakan sejarah buruk lawan secara berlebihan dan bisa juga berupa tindakan menguraikan kesalahan lawan politik ke media. ${ }^{6}$ Sedangkan, kampanye hitam menurut Hafied Cangara (2009:4) cenderung menyudutkan para calon yang diusung untuk menduduki suatu jabatan dan isu tersebut biasanya dikaitkan dengan korupsi, wanita dalam bentuk istri simpanan atau perselinguhan dan takhta yang diakaitkan dengan sikap ambisius. ${ }^{7}$ Maka dapat ditarik kesimpulan bahwa kampanye negatif dan hitam sering digunakan elit politik untuk menjatuhkan lawan politiknya atau sekedar menceritakan sejarah buruk lawan politiknya dengan media.

\section{Media Sebagai Mediator Masyarakat Informasi}

Perilaku politik melalui internet awalnya hanya bayangan belaka, tetapi dalam jangka waktu sepuluh tahun belakangan angan-angan itu telah berkembang menjadi peristiwa yang sangat rutin yang tak bisa diabaikan pelaku politik dan masyarakat sipil. Pembicaraan tentang masyarakat informasi, kontribusi dalam hal material seperti

\footnotetext{
${ }^{4}$ Setianto, Widodo A,. (2008). Konvergensi Media Periklanan dalam konstelasi Perkembangan Teknologi Media. Vol 12 (2) 121-256.

${ }^{5}$ Cipto, Bambang, (2003). Politik dan Pemerintahan Amerika, Yogyakarta: Lingkaran. Hal: 105.

${ }^{6}$ Lilleker, Darren G (2006). Key Concept in Political Communication. London: SAGE publications. Hal:127.

${ }^{7}$ Cangara, Hafied. (2009). Komunikasi Politik. Jakarta: PT. Raja Grafindoo Persada. Hal: 4.
} 
kegiatan bermedia dan berkomunikasi melalui teknologi yang secara langsung digunakan untuk mewujudkan produk media dan produk informasi, dan secara tidak langsung berupa konsumen.

Berbagai lapisan masyarakat menggunakan media untuk mengankses informasi sesuai dengan yang di butuhkan. Pilihan atas akses informasi di Indonesia sangat beragam mulai dari media maintream ataupun media baru. Internet hingga saat ini menjadi komoditi utama masyarakat dalam mecari informasi yang mereka butuhkan, hal ini dapat dilihat melalui hasil survey yang diselenggarakan oleh Asosiasi Penyelenggara Internet Indonesia (APJII) dan berkolaborasi dengan lembaga polling pada tahun 2016. Sebagian besar pengguna internet di Indonesia tinggal di pulau jawa, tepatnya 86,3 juta orang atau sekitar $65 \%$. Pulau sumatera berada pada urutan kedua dengan 20,75 juta $(15,7 \%)$ dan pulau sulawesi berada di peringkat kedua dengan 8,45 juta $(6,3 \%)$. Berikutnya, kalimantan (5,8\%), Bali-Nusa $(4,7 \%)$ dan maluku sampai papua $(2,5 \%) .{ }^{8}$ Hal ini didukung oleh perkembangan teknologi komunikasi atau perangkat pendukung lainnya yang semakin canggih. Perangkat teknologi tersebut seperti, Smartphone, laptop, tablet dan akses wireless menggunakan jaringan satelit. Artinya dengan basis material inilah moda komunikasi dapat diproduksi dan dapat sampai kepada masyarakat.

Hak masyarakat berkomunikasi pada hakikatnya berada dalam lingkup konsep kebebasan pers, yang mencakup suatu rantai dalam proses demokrasi, sebagai implementasi dari hak azasi manusia (HAM) sesuai Deklarasi Hak Azasi Manusia $1948^{9}$ dan Perjanjian Internasional Hak-Hak Sipil dan Politik $1966^{10}$. Keberadaan institusi pers bebas dilihat dalam konteks proses ini. Secara konvensional proses demokrasi mencakup dinamika kehidupan masyarakat yang dikenal sebagai fakta publik (public fact).

Masalah publik (public issue) dapat diartikan sebagai fakta yang berasal dari respon warga terhadap ketidakpuasan pemimpin atau orang yang berkuasa. Umumnya seseorang akan mencari informasi tentang hak dan memperoleh haknya sesuai dengan regulasi yang berlaku yang kemudian disiarkan secara bebas (otonom dan independen). Pikiran dan pendapat publik yang terbentuk sebagai respon dari masalah publik menjadi

\footnotetext{
${ }^{8}$ https://apjii.or.id/downfile/file/BULETINAPJIIEDISI05November2016 .Buletin APJII edisi 5 November 2016.

${ }^{9}$ Deklarasi Hak Azasi Manusia 1948 pasal 19: Setiap orang berhak atas kebebasan beropini dan berekspresi; hak ini meliputi kebebasan untuk memiliki opini tanpa intervensi serta untuk mencari, menerima, dan mengungkapkan informasi serta gagasan melalui media apa pun dan tidak terikat garis perbatasan.

${ }^{10}$ Perjanjian Internasional tentang Hak-Hak Sipil dan Politik 1966 pasal 19:

-Setiap orang harus berhak untuk memiliki opini tanpa intervensi.

-Setiap orang harus berhak atas kebebasan berekspresi; hak ini harus meliputi kebebasan untuk mencari, menerima serta mengungkapkan segala jenis informasi dan gagasan, terlepas dari garis perbatasan, secara lisan, tulisan atau tercetak, dalam bentuk karya seni, atau melalui segala media lain pilihannya sendiri. -Pelaksanaan hak-hak yang dijamin dalam ayat 2 Pasal ini membawa kewajiban-kewajiban dan tanggung jawab-tanggung jawab tersendiri. Karenanya hal ini tunduk pada pembatasan-pembatasan tertentu, tetapi ini hanya boleh dilakukan sebagaimana yang ditetapkan oleh hukum dan yang diperlukan: Untuk menghargai hak atau nama baik orang lain; Untuk melindungi keamanan nasional atau ketertiban umum, atau kesehatan atau kesusilaan umum.
} 
dasar dari kehidupan publik. Maka dari itu tidak semua fakta yang terjadi di tengah masyarakat relevan sebagai dasar pembentukan pendapat publik. Tubbs dan Moss (2000) berpendapat bahwa, "teknologi baru dalam komunikasi dapat dianggap sebagai perluasan media yang lebih interaktif dan menuju pada tatanan global". ${ }^{11}$ Secara sederhana teknologi baru yang dapat dikatakan juga sebagai media baru dapat mengaburkan batasan geografis suatu negara dan menjadi konsusi publik. Maka dari itu audiens pengguna internet hendaknya memahami hakikat kebebasan dalam penggunaan media baru. Sebab, ada kecenderungan pengguna media di indonesia khusunya remaja tidak menghiraukan norma dalam interaksi komunikasi dalam wilayah publik.

Komunikasi menggunakan media baru, meskipun fleksibel namun tetap harus tunduk kepada UU N0.14 Tahun 2008 dan Undang-Undang Republik Indonesia Nomor 11 tahun 2008, tentang Informasi dan Transaksi Elektronika (UU ITE). Undang-undang keterbukaan Informasi publik menjamin transparansi dan demokratisasi informasi yang mendukung terbentuknya kesejahteraan masyarakat informasi. Sedangkan UU No.11 2008, mengatur tentang penggunaan teknologi komunikasi masyarakat dan elite politik dalam berinteraksi dengan media baru, mereka wajib mengetahui UU ITE. Sebab, tanpa memahami dengan sungguh-sungguh, dikahawtirkan dalam berkampanye dan menyuarakan aspirasinya terjebak dan melakukan kesalahan. UU No.11 yahun 2008 ini bahkan dari 54 pasal yang ada didalamnya, terdapat pasal tentang "perbuatan yang dilarang" merupakan aturan terbanyak, karena mencapai 11 pasal, dengan 24 butir ketentuan yang harus menjadi perhatian bagi mereka yang menggunakan internet.

Diantara ketentuan yang berpotensi menyeret pengguna internet dalam ranah hukum, antara lain terdapat dalam pasal 27 ayat (2), Setiap orang dengan sengaja dan tanpa hak mendistribusikan atau mentransmisikan atau membuat dapat diaksesnya Informasi Elektronik atau Dokumen Elektronik. Termasuk muatan perjudian, pencemaran nama baik dan pemerasan atau pengancaman juga dilarang. Ketentuan yang seringkali juga tidak dihiraukan oleh elit politik menyangkut pasal 28 ayat (1) Setiap orang dengan sengaja dan tanpa hak menyebarkan berita bohong dan menyesatkan yang mengakibatkan kerugian konsumen dalam transaksi elektronika.

Kemudian, Pasal 28 ayat (2) Setiap orang dengan sengaja dan tanpa hak menyebarkan informasi yang ditujukan untuk menimbulkan rasa kebencian atau permusuhan individu atau kelompok masyarakat tertentu berdasarkan atas SARA (suku, agama, ras dan antar golongan). Pasal 29, Setiap orang dengan sengaja dan tanpa hak mengirimkan Informasi Elektronik yang berisi ancaman kekerasan atau menakut-nakuti yang ditujukan secara pribadi. Seperti kasus pemilihan kepala daerah khusus ibukota Jakarta tahun 2017 baru-baru ini. Tingginya persaingan antar pasangan calon pilgub DKI membuat persaingan itu sendiri diwarnai oleh isu SARA yang menimbulkan kegaduhan

${ }^{11}$ Tubbs, Stewart L dan Sylvia Moss .(2000). Human Communication: Konteks-Konteks Komunikasi, Buku I dan Buku II, terjemahan Deddy Mulyana dan Gembirasari, Bandung : PT. Remaja Rosda Karya. Hal: 225 
di seluruh wilayah di Indonesia. Statement Ahok sebagai kandidat gubernur DKI di kepulauan seribu yang telah membawanya menjadi tersangka kasus penistaan agama.

Dalam melihat hak-hak warga negara T.H Marshall dalam Murdock dan Golding (1989) menjelaskan bahwa terdapat tiga dimensi hak-hak kewarganegaraan antara lain (1) aspek Sosial, (2) aspek politik dan (3) aspek sipil. ${ }^{12}$ Hak-hak warga negara dalam aspek sipil dan politik berkenaaan langsung kepada hakikat manusia. Hak-hak untuk bergerak, bebas berpendapat, berekspresi, berpikir dan beragama baik dalam berpolitik dan mengkritisi pemerintah. Hak-hak warga negara dalam aspek politik sangat berhubungan dengan keikutsertaan warga negara dalam proses dan hasil dari kegiatan politik.

Sebagaimana diketahui, bahwa jaringan internet yang sangat terbuka seperti laman web dan sosial media Facebook, Twitter dan blog ataupun yang lainnya, sifatnya sangat terbuka. Dalam arti mudah diakses oleh publik, karena itu dalam penggunaannya untuk mengkritik atau menyuarakan tuntutan demokrasi, hendaknya diperhatikan juga norma dan peraturan yang berlaku. Jangan sampai komunikasi publik yang dilakukan berujung pada tuntutan hukum, karena bertentangan dengan peraturan yang terdapat dalam UU ITE.

\section{Internet dan Komunikasi Politik}

Selain media massa, kini para elit politik maupun partisan politik menggunakan media internet sebagai sarana komunikasi, informasi dan persuasi ke masyarakat. Hal ini bisa dilihat dengan semakin banyaknya situs-situs di internet (websites) yang menyediakan informasi dalam arti luas (tulisan, audio visual) berkaitan dengan profil, berita, ataupun pemilihan umum. Situs-situs tersebut memberikan lengkap dan persuasif karena situs-situs tersebut merupakan tampilan gabungan dari media cetak dan media audio visual.

Fenomena maraknya penggunaan internet memunculkan media sosial yang memungkinkan penggunanya saling bertukar informasi dan memiliki data pribadi. Media sosial sebagai sarana komunikasi memiliki peran membawa penggunanya untuk berpartisipasi secara aktif dengan memberi kontribusi serta respon secara terbuka, baik untuk membagi informasi maupun memberi respon secara online dalam waktu yang cepat. Media sosial seperti, facebook pada awalnya cenderung berkait pada persoalan pertemanan. Namun dewasa ini, telah banyak menyinggung ke ranah politik keuaasaan pemerintahan atau negara.

Media Internet termasuk media alternatif dan cukup cepat daya respon audiens karena audiens media ini dapat mengomentari dan mengkritik langsung pesan yang disampaikan. Kekuatan internet melingkupi konteks komunikasi antarpribadi,

\footnotetext{
${ }^{12}$ Murdock, G. \& Golding.P. (1989). Information Proverty and Political Inequality: Citizenship in The Age of Privatized Communications. Journal of Communication. Vol.39(3), 180-195.
} 
komunikasi kelompok dan komunikasi massa. Tidak heran kini para elit politik maupun partisan politik juga aktif menggunakan media internet, dalam bentuk blog maupun media sosial untuk melobi dan berkomunikasi kepada partisan. Saat sekarang ini agak aneh bila para calon legislatif tidak memiliki dan menggunakan internet seperti website pribadi, Facebook, Twitter, blog atau yang lainnya.

Raiz mengatakan, "Today, we are living in digital word where new media technology has changed the word. We all have been heavily innuinced by new media technology. We'r all use internet for information and connection pupose. The advent of internet has drasticcally changed our life styles. ${ }^{13}$ Internet sebagai bentuk dari perkembangan teknologi telah mengubah dunia. Gaya hidup, prilaku dan interaksi masyarakat hingga saat ini banyak dipengaruhi oleh internet.

Situs-situs elit politik menampilkan seperti apa yang dipublikasikan oleh media massa cetak sekaligus juga bisa menampilkan sebagaimana yang disiarkankan oleh media konvensional. George Clack dan kawan-kawan (2000:42) menyatakan bahwa internet mengubah cara komunikasi politik dan sekaligus mengubah wacana publik dengan cara yang halus. ${ }^{14}$ Begitu kuatnya pengaruh Internet terhadap sendi-sendi kehidupan manusia sehingga komunikasi politik dapat disampaikan secara halus dan intens.

Setiap individu dapat menyampaikan keluhan, tuntutan, dan harapan mereka secara langsung kepada pemerintah maupun pejabat pemerintah tanpa dibatasi oleh ruang dan waktu. Lebih lanjut George Clack dan kawan-kawan menambahkan: "As access to the internet grows, and it becomes easier to use, the internet will rise as a major means of political communication. Over the next 10 years, as a new political generation comes on-line, the internet will probably surpass television as the main mode of communication. And with the internet will come an even greater ability for the public to talk back. ".

Kutipan ini menunjukkan bahwa internet di masa mendatang akan menjadi salah satu media yang sangat berpengaruh atau bahkan bisa menjadi media yang unggul, khususnya dalam dunia politik dan pemerintahan, yang dalam hal ini pemerintahan Amerika. Perubahan cara komunikasi politik ini juga dimanfaatkan oleh para elit politik Indonesia, khususnya para tim pelaksana kampanye kepresidenan dengan menggunakan internet sebagai sarana komunikasi dan persuasi demi keberhasilan kerja mereka.

\section{Citra dan Dinamika Elit Politik dalam Era Virtualitas}

Berbagai metode seperti pemberitaan, iklan, propaganda, kampanye, reaksi publik dan lainnya sebagai bagian dari proses komunikasi politik. Padahal komunikasi itu sendiri mestinya harus dibangun jauh-jauh hari, hal ini sesuai dengan prinsip komunikasi adalah

\footnotetext{
${ }^{13}$ Riaz. Saqib. (2010). Effect of New Media Technologies on Political communication. Journal of politikal studies, Vol.1 Iss.2.

${ }^{14}$ Clack, George (ed), (2000). United States Elections, U.S. Department State, Office of International Information Programs.
} 
proses. Memang secara umum proses kampanye dalam pemilu interaksi politik berlangsung dalam tempo dan suhu politik yang semakin meningkat menjelang pemilihan. Setiap peserta melakukan komunikasi dan berkampanye untuk meyakinkan para pemilih.

Dalam prakteknya, komunikasi politik sangat kental dalam kehidupan masyarakat sehari-hari. Dalam aktivitas sehari-hari tidak satupun orang tidak berkomunikasi, baik dalam membicarakan fenomena kenaikan harga kenaikan bahan bakar (BBM) yang sebenarnya telah mengarah kepada analisis komunikasi politik. Hal yang kurang lebih sama terjadi dalam konteks pembicaraan pemilihan kepala daerah maupun kepala negara dalam pemilihan umum yang diselenggarakan oleh KPU (Komisi Pemilihan Umum). Pada saat menjelang pemilihan umum perbincangan mengenai calon yang diusung oleh partai tertentu banyak muncul di media sosial. Akan tetapi ada pihak yang memanfaatkan momen ini sebagai ajang untuk sarana penistaan, pencemaran nama baik seseorang ataupun kelompok agar kredibilitasnya jatuh.

Seperti, pada pilgub DKI Jakarta tahun 2017 kemarin keberadaan tiga pasangan calon Gubernur dan Wakil Gubernur cepat tersosialisasi dalam media sosial seperti yang diunggah dalam akun Facebook masing-masing pasangan atau media sosial yang dikembangkan masyarakat. Akan tetapi banyak para netizen di sosial media yang memberikan Feedback Negatif dan cenderung memojokkan salah satu kandidat. Dalam demokrasi, sangat wajar adanya perbedaan pendapat dan pandangan ketika komunikasi politik di tengah masyarakat berlangsung. Akan tetapi, pernyataan dan keyakinan masyarakat atas apa yang disampaikannya melalui kolom komentar di media sosial cenderung memojokkan dan memfitnah calon yang diusung.

Komentar negatif ini biasanya dalam bentuk kata-kata menghujat, sarkastis, dan menjatuhkan kandidat. Laman facebook Agus-Silvy misalnya, banyak sekali mendapatkan pernyataan tidak mendukung dan bahkan penghujatan. Kasus lain serupa pada muatan pesan bernada negatif adalah pesan-pesan dengan kata-kata yang bersifat pelecehan dan hujatan, yang ditujukan pada pendukung kandidat Cagub atau Cawagub No. urut 1. Misalnya, dalam laman facebook, ditemukan kalimat, "si KEBO Cikeas PENGHASUT Keributan". Kata-kata lain yang negatif adalah "SBY busuk jahat takut anaknya kalah". Sementara itu, akun atas nama Mia Samia2, menuliskan, "sadar pak sby harta dan jabatan ga bisa di bawa mati uang triliunan juga ga dibawa mati, hanya mati bawa kaen putih sama amal ibadah. Jangan Islam dijual karna gila harta." Lalu, soeisian ss5 menuliskan, "Sby busuk jahat takut anaknya kalah."15

Tulisan-tulisan serta komentar-komentar kasar diatas bukan tidak mungkin disebabkan oleh pesaing politik itu sendiri. Seperti yang kita tahu kasus Saracen. Saracen yang merupakan grup penyebar kebencian atau isu SARA dan hoax di media sosial

\footnotetext{
${ }^{15}$ Juniawan, Roby,. (2015). Pengaruh Black Campaign Terhadap Persepsi Pemilih Pada Pilpres Tahun 2014. Yogyakarta: Universitas Muhammadiyah Yogyakarta.
} 
facebook diduga kuat jasanya dipakai oleh sejumlah elit politik. Tujuannya tidak lain untuk menyebarkan konten-konten negatif yang cenderung mendramatisir keadaan sehingga publik merasa bingung dan setelah itu dengan mudah mereka menggiring opini publik.

Pengamat Media Sosial dari Provetic, Iwan Setiawan, menilai perbuatan sindikat penyebar ujaran kebencian atau isu SARA dan hoax seperti grup Saracen, berakibat buruk bagi keutuhan negara. Hal tersebut didasari analisa Iwan yang melihat hate speech perorangan mampu memberi dampak pada masyarakat luas, apalagi jika dilakukan terorganisir seperti Saracen. Iwan mengatakan "Yang mereka lakukan kan di media sosial kan bagaimana menggiring opini orang ya. Dengan konten yang terorganisir seperti itu, itu impactnya akan jauh lebih besar daripada konten (isu) yang dilemparkan perseorangan". ${ }^{16}$ Menggiring opini melalui media sosial lebih gampang bila pendistribusian kontennya terorganisir seperti yang di lakukan oleh saracen. Iwan Setiawan menilai perbuatan sindikat penyebar ujaran kebencian atau isu SARA dan hoax seperti grup Saracen, berakibat buruk bagi keutuhan negara. Hal tersebut didasari analisa Iwan yang melihat hate speech perorangan mampu memberi dampak pada masyarakat luas, apalagi jika dilakukan terorganisir seperti Saracen.

Dalam perkembangan kasus Saracen, polisi akhirnya menangkap seorang ibu rumah tangga bernama Asma Dewi yang diduga telah melakukan ujaran kebencian. Awalnya polisi menemukan adanya dugaan ujaran kebencian yang dilakukan Asma Dewi melalui posting-an di Akun Facebook atas nama ASMA DEWI ALI HASJIM. Setidaknya, ada empat postingan yang diduga polisi sebagai bukti permulaan ujaran kebencian bernuansa SARA yang dilakukan Asma Dewi. Pertama pada 21 Juli 2016, Asma Dewi menulis status diakun Facebook-nya dengan caption: "KALAU DISINI. WAJIB BELAJAR BAHASA CHINA..(dengan emoticon tertawa)".

Kedua, melakukan postingan melalui akun Facebook lainnya atas nama ASMA DEWI pada 22 Juli 2016, dengan caption: "Wah parah semua yg nggk beres china". Ketiga, melakukan postingan melalui akun Facebook atas nama ASMA DEWI pada 22 Juli 2016, dengan caption: Rezim koplak. Diluar negri dibuang disini di sini disuruh. Makan rakyatnya. Keempat, melakukan postingan melalui akun Facebook ASMA DEWI pada 22 Juli 2016, dengan caption gambarnya: Beredar Pesan Untuk TKI Agar Hati-Hati Bawa Tas Jangan Sampai Terbuka, Karena China Akan Hancurkan Indonesia Lewat TKI-Suara BMI. ${ }^{17}$

Sindikat Saracen bekerja secara profesional dalam mengolah isu SARA dan kebencian di media sosial. Salah satu contoh profesionalitas Saracen adalah mereka menggunakan target pasar dalam mendistribusikan konten-kontennya. Seperti konten

16 https://news.detik.com/berita/3616459/saracen-penyebar-konten-sara-yang-dapat-memecah-belahbangsa.

${ }^{17}$ http://news.liputan6.com/read/3091745/kronologi-penangkapan-asma-dewi-terkait-sindikat-saracen. 
yang terdapat di akun facebooknya Asma Dewi diatas. Awalnya, grup Saracen menyebar proposal ke sejumlah elit politik (calon klian) dengan mencantumkan harga. Kemudian jumlah uang itu dibagikan untuk membuat situs website dan membayar sejumlah anggota Saracen untuk membuat ujaran kebencian.

Kesadaran akan keberagaman dan hidup saling menghormati, merawat toleransi antar-sesama sangat tinggi sebenarnya ada pada masyarakat Indonesia. Akan tetapi, adanya sindikat Saracen dan intensnya elite politik melakukan kampanye negatif dan hitam menjelang pemilu untuk memperoleh citra baik dari masyarakat cenderung berimbas kepada kekhawatiran perpecahan diantara masyarakat Indonesia yang sebenarnya memiliki toleransi yang kuat antarsesama. Para elite seharusnya menjunjung tinggi akhlak politik atau etika politik mereka, bukan menghalalkan segala cara untuk menjatuhkan lawan politik mereka.

\section{Penutup}

Media internet tidak saja berguna bagi elit politik dalam membangun citra akan tetapi berguna untuk masyarakat dalam memperoleh dan menyaring informasi apa saja megenai kegiatan politik. Internet telah menjadi media yang cukup besar pengaruhnya terhadap perubahan politik dalam masyarakat Indonesia. Hampir semua hal yang berkaitan dengan politik dan pemerintahan sekarang bisa diakses lewat website lembaga mereka masing-masing. Setiap warga Indonesia dapat menyampaikan keluhan, tuntutan, dan harapan mereka secara langsung kepada pemerintah maupun pejabat pemerintah tanpa dibatasi oleh ruang dan waktu. Di masa mendatang internet akan menjadi salah satu media yang sangat berpengaruh atau bahkan bisa menjadi media massa yang unggul, khususnya dalam dunia politik dan pemerintahan di Indonesia.

Internet mengubah cara komunikasi politik. Tidak heran bila seiring meningkatnya pengguna internet di Indonesia maka komunikasi politik dan wacana publik di Indonesia akan ikut berubah. Perubahan ini tentunya dapat mengubah wajah demokrasi di Indonesia lebih terbuka dengan kontrol publik sepenuhnya, selaras dengan karakteristik yang dimiliki oleh Internet. Akan tetapi perubahan ini belum sepenuhnya berhasil. Adanya praktek curang elit politik seperti kampanye hitam dan kampanye negatif serta hidupnya sindikat Saracen, dinilai merusak wajah demokrasi dan dapat menimbulkan perpecahan warga Indonesia.

Ketidakjelasan undang-undang No. 11 Tahun 2008, mengenai informasi dan Transaksi Elektronik juga dinilai merupakan penyebabnya. Namun, kita juga harus mengapresiasi usaha pemerintah dalam membuat regulasi tersebut. Karena itu, audiens atau masyarakat termassuk elit politik sendiri harus memahami berbagai regulasi yang mengatur tentang kebebasan komunikasi. Sebab, media baru yang didukung oleh jaringan internet, yang merepresentasikan ruang publik dalam media online, tidak bisa dipakai untuk menyuarakan tuntutan demokrasi, dengan mengabaikan berbagai ketentuan yang sudah diatur. 


\section{Daftar Referensi}

Abrar, Ana Nadya. (2003). Teknologi komunikasi, Perspektif Ilmu Komunikasi. Yogyakarta: Lesfi.

Cangara, Hafied. (2009). Komunikasi Politik. Jakarta: PT. Raja Grafindoo Persada.

Cipto, Bambang, (2003). Politik dan Pemerintahan Amerika,. Yogyakarta: Lingkaran.

Clack, George (ed), (2000). United States Elections, U.S. Department State, Office of International Information Programs.

Juniawan, Roby,. (2015). Pengaruh Black Campaign Terhadap Persepsi Pemilih Pada Pilpres Tahun 2014. Yogyakarta: Universitas Muhammadiyah Yogyakarta.

Lilleker, Darren G (2006). Key Concept in Political Communication. London: SAGE publications.

McQuail, Denis. (2011). Teori Komunikasi Massa. Buku 1. Edisi 6. Jakarta: Salemba Humanika.

Murdock, G. \& Golding.P. (1989). Information Proverty and Political Inequality: Citizenship in The Age of Privatized Communications. Journal of Communication . Vol. 39(3), 180-195. 
Nimmo, Dan. (2005). Komunikasi Politik. Komunikator, Pesan, dan Media. Bandung: Remaja Rosda Karya.

Riaz. Saqib. (2010). Effect of New Media Technologies on Political communication. Journal of politikal studies, Vol.1 Iss.2.

Setianto, Widodo A,. (2008). Konvergensi Media Periklanan dalam konstelasi Perkembangan Teknologi Media. Vol 12 (2) 121-256.

Torach Julius \& Bitwayiki Constantine. (2006). Uganda Puths ICTs Under One Political Leadership Presentation at GTEC/CePRC eGovernment Workshop. Ottawa.

Tubbs, Stewart L dan Sylvia Moss .(2000). Human Communication: Konteks-Konteks Komunikasi, Buku I dan Buku II, terjemahan Deddy Mulyana dan Gembirasari, Bandung : PT. Remaja Rosda Karya.

Varma, S.P. (2010). Teori Politik Modern. Penyunting Tohir Efendi. Jakarta: PT. Raja Grafindo Persada.

\section{Sumber lain:}

Audrey Santoso, detik.com. Saracen, Penyebar Konten SARA yang Dapat Memecah $\begin{array}{lllll}\text { Belah } & \text { Bangsa. } & \text { Edisi } & 27 & \text { Agustus }\end{array}$ (https://news.detik.com/berita/3616459/saracen-penyebar-konten-sara-yangdapat-memecah-belah-bangsa) diakses pada 20 November 2017. Pukul 15:00 WIB.

$\begin{array}{lllll}\text { Buletin } & \text { APJII } & \text { edisi } & 5 & \text { november }\end{array}$ (https://apjii.or.id/downfile/file/BULETINAPJIIEDISI05November2016)diakses pada: 1 Oktober 2017. Pukul 20:45 WIB.

Deklarasi Universal Hak-Hak Azasi Manusia. (1948). Diterima dan diumumkan oleh Majelis Umum PBB pada tanggal 10 Desember 1948 melalui resolusi 217 A (III).

Hanz Jimenez Salim., Liputan6.com, Kronologi Penangkapan Asma Dewi Terkait $\begin{array}{lllll}\text { Sindikat } & \text { Saracen. } & \text { Edisi } & 12 & \text { September }\end{array}$ (http://news.liputan6.com/read/3091745/kronologi-penangkapan-asma-dewiterkait-sindikat-saracen) diakses pada 20 November 2017. Pukul 15:25 WIB.

Tribunnews.com., edisi 21 September 2017, Polisi Pegang Bukti Foto Keterlibatan Tokoh Parpol dalam Sindikat Saracen,. (http://www.tribunnews.com/nasional/2017/09/21/polisi-pegang-bukti-fotoketerlibatan-tokoh-parpol-dalam-sindikat-saracen). Diakses pada tanggal 20 November 2017. Pukul 14:00. 
